\title{
ANALISIS FAKTOR-FAKTOR DOMINAN TENTANG KEPUASAN KONSUMEN DALAM PEMBELIAN RUMAH PADA PROYEK PERUMAHAN PERSADA MAS BANJARMASIN
}

\section{ANALYSIS OF DOMINANT FACTORS CONCERNING CUSTOMER SATISFACTION IN BUYING A HOUSE IN PERSADA MAS BANJARMASIN HOUSING PROJECT}

\author{
Elva Shanty Widuri \\ Jurusan Teknik Sipil Fakultas Teknik Universitas Achmad Yani Banjarmasin \\ Korespondensi: elva.shantywiduri99@gmail.com
}

\begin{abstract}
ABSTRAK
Untuk mengetahui faktor-faktor dominan tentang kepuasan konsumen dalam membeli rumah pada proyek perumahan harus ada keterlibatan antara pihak pengembang dan konsumen. Hal ini dimaksudkan agar dapat mengetahui prioritas dan harapan konsumen dalam membeli rumah pada proyek perumahan tersebut. Pentingnya mengetahui kepuasan konsumen ini untuk membuat strategi dalam usaha memperbaiki dan meningkatkan kualitas produk perumahan. Kepuasan konsumen sangat tergantung dari fasilitas itu, faktor apa sajakah yang dominan tentang kepuasan konsumen dalam membeli rumah pada proyek perumahan. Faktorfaktor dominan yang diinginkan konsumen dalam membeli rumah didapatkan dari informasi konsumen yang tinggal di daerah itu. Informasi ini diperoleh melalui penyebaran kuesioner yang kemudian diolah dengan analisis validitas, analisis reliabilitas, analisis faktor dan analisis tabulasi silang. Dengan mendapatkan faktorfaktor dominan tentang kepuasan konsumen dalam membeli rumah pada proyek perumahan pihak pengembangan dapat memperbaiki dan meningkatkan fasilitas yang ada sekarang agar konsumen merasa puas sehingga menjadi sumber dari daya saing yang berkelanjutan.
\end{abstract}

Kata kunci : Analisis faktor, analisis tabulasi silang, faktor dominan, kepuasan konsumen

\begin{abstract}
To find out the dominant factors about consumer satisfaction in buying a house in a housing project, there must be involvement between the developer and the consumer. This is intended to find out the priorities and expectations of consumers in buying a house in the housing project. The importance of knowing consumer satisfaction is to make strategies in an effort to improve and improve the quality of housing products. Customer satisfaction really depends on the facility, what are the dominant factors about consumer satisfaction in buying a house in a housing project. The dominant factors that consumers want in buying a house are obtained from information on consumers who live in the area. This information is obtained through distributing questionnaires which are then processed by validity analysis, reliability analysis, factor analysis and cross tabulation analysis. By getting the dominant factors about consumer satisfaction in buying a house in a housing project, the development party can improve and improve existing facilities so that consumers feel satisfied so that they become a source of sustainable competitiveness.
\end{abstract}

Keywords: customer satisfaction, cross tabulation analysis, dominant factors, factor analysis 


\section{PENDAHULUAN}

\section{Latar Belakang}

Adanya dua pelaku utama dalam bisnis perumahan yakni pengembang sebagai supplier dan pembeli sebagai customer masing-masing memiliki orientasi kepentingan yang berbeda. Pengembangan berorientasi pada sisi bisnis sedangkan konsumen berorientasi kepada pemenuhan kebutuhan papan dengan harga yang terjangkau dan kualitas yang layak huni. Berkaitan dengan hal itu, maka perlu adanya keterlibatan antara pihak pengembangan dan konsumen dalam proses pembangunanproyek perumahan. Bentuk keterlibatan konsumen dalam proyek pembangunan perumahan ini adalah dengan cara menyampaikan keinginan atau kebutuhan konsumen terhadap pengembangan melalui reset pasar dan salah satu bentuk riset pasar adalah dengan melakukan survey kepuasan konsumen.

Riset pasar ini berguna untuk mengatahui kebutuhan, harapan dan keinginan konsumen dalam produk perumahan. Adanya umpan balik yang terjadi antara pengembangan dan konsumen ini sehingga dapat diketahui bagaimana sikap dan penilaian konsumen terhadap produk perumahan. Umpan balik tersebut merupakan suatu proses perbaikan maupun peningkatan kualitas pada proyek perumahan, kebutuhan, harapan, dan keinginan konsumen tentu berbeda-beda. Dalam hal ini segmen pasar yang diteliti adalah segmen pasar menengah keatas dan keutuhan, harapan dan keinginan terhadaprumah menjadi semakin banyak karena rumah bukan hanya sebagai tempat berteduh tetapi juga untuk menunjukkan kelas sosial di masyarakat.

\section{Rumusan Masalah}

Berdasarkan kondisi-kondisi tersebut dapat dirumuskan masalah sebagai berikut:

- Faktor-faktor apa sajakah yang dominan tentang kepuasan konsumen dalam pembelian rumah pada proyek perumahan?

\section{Tujuan Penelitian}

- Mendapatkan faktor-faktor dominan tentang kepuasan konsumen dalam pembelian rumah pada proyek perumahan.

\section{Manfaat Penelitian}

- Dengan mendapatkan faktor-faktor dominan tentang kepuasan konsumen dalam pembelian rumah di proyek perumahan sehingga dapat diketahui kebutuhan, harapan dan keinginan konsumen dan dapat membuat strategi dalam usaha memperbaiki dan meningkatkan kualitas produk perumahan.

\section{TINJAUAN PUSTAKA}

\section{Mengelola Kepuasan Konsumen}

Ada lima hal mengelola kepuasan konsumen yaitu : (Philip Kotler 1994)

1. Keandalan (reliability) yaitu kemampuan untuk melaksanakan jasa yang di sajikan dengan tepat dan terpercaya.

2. Keresponsifan (responsiveness) yaitu kemauan untuk membantu konsumen dan memberikan jasa dengan cepat dan ketanggapan.

3. Keyakinan (confidence) yaitu pengetahuan dan kesopanan karyawan serta kemampuan mereka untuk menimbulkan kepercayaan dan keyakinan.

4. Empati (empaty) yaitu syarat untuk peduli, memberi perhatian pribadi bagi konsumen.

5. Berwujud (tangible) yaitu penampilan fasilitas fisik, peralatan, personel dan media komunikasi.

\section{Aspek Kebutuhan Konsumen Perumahan}

Menurut pedoman perencanaan lingkungan pemukiman kota yang disusun oleh Direktorat Tata Kota dan Tata Daerah bekerja sama dengan Direktorat Pendidikan Maslah Bangunan, 1983.

Rumah adalah bangunan yang berfungsi sebagai tempat tinggal atau hunian dan srana pembinaan keluarga.

Perumahan adalah sebagai salah satu sarana hunian yang sangat erat kaitannya dengan tata cara kehidupan masyarakat.

\section{Metode-metode Pengumpulan Informasi Konsumen}

Ada 3 metode pengumpulan informasi konsumen yaitu:

1. Metode Observasi, yaitu metode yang mengamati kebiasaan konsumen dalam membeli produk tertentu, sikap dan 
penilaian konsumen terhadap produk dan jenis-jenis produk yang disukai oleh konsumen.

2. Metode Eksperimen, yaitu metode pengumpulan data dengan mengadakan eksperimen atau percobaan terhadap situasi, misalnya mengukur pengaruh situasi khusus terhadap sikap pembeli.

3. Metode Survey, yaitu metode pengumpulan data atau informasi konsumen dengan melakukan partisipasi secara aktif.

Ada 4 teknik dalam metode survey, yaitu wawancara pribadi (personal interviev), survey melalui kuesioner (quesioner surveys), yaitu:

a. Wawancara pribadi, wawancara probadi merupakan teknik pengumpulan informasi yang dilakukan dengan interaksi langsung berhadap-hadapan antara pewawancara dengan konsumen.

b. Survey melalui telepon, yaitu teknik pengumpulan informasi konsumen melalui telepon dimaksudkan untuk mengetahui pendapat konsumen terhadap produk yang telah dibelinya.

c. Survey melalui surat, yaitu pengumpulan informasi melalui surat untuk menyebarluaskan pertanyaan kepada konsumen melalui media pos. Diharapkan dapat mengisi pertanyaan dan mengirimkannya kembali.

d. Survey melalui kuesioner, yaitu mengukur tingkat kepuasan konsumen melalui kuesioner yang disebarkan untuk mendapatkan data yang diinginkan.

\section{Uji Vadilitas}

Uji vadilitas adalah uji untuk mengetahui seberapa cermat dan tepat suatu kuesioner harus valid dalam menentukan fungsi ukurnya. Semakin tinggi vadilitas alat ukur, maka semakain kecil variabel kesalahannya.

Suatu ukuran (measurement) dapat diterima secara ilmiah jika memenuhi dua persyaratan yaitu sah (valid) dan terpercaya (reliable). Ada 3 jenis validasi yang paling banyak digunakan,yaitu validitas konstruk (construct validity).

Dalam validitas konstruk hubungan empiris ukuran-ukuran tersebut diukur korelasi antara skor-skor tiap variabel dengan skor total. Hasil korelasi masing-masing variabel kemudian dibandingkan dengan $r$ tabel pada tingkat kepercayaan dan derajat bebas yang bersesuaian. Dalam hal ini hipotesis yang digunakan adalah:

Ho : skor variabel berkorelasi positif dengan skor total

$\mathrm{H}_{1} \quad$ : skor variabel tidak berkorelasi positif dengan skor total

Suatu variabel dikatakan valid jika Ho diterima. Dengan menggunakan angka korelasi yang dihasilkan maka suatu variabel dikatakan valid jika $r$ olah $>r$ tabel. Secara statistik, angka korelasi yang diperoleh harus dibandingkan dengan angka kritik tabel korelasi nilai r. Cara melihat angka kritik adalah dengan melihat bari $\mathrm{n}-$ 2. Variabel yang dinyatakan valid harus berada di atas angka kritik $5 \%$ sehingga dapat diartikan bahwa variabel-variabel pertanyaan tersebut memiliki validitas konstruk, yang artinya memiliki konsistensi internal dimana pertanyaan-pertanyaan dalam variabel tersebut mengukur aspek yang sama

Jika suatu variabel disimpulkan tidak valid, maka variabel tersebut harus dikeluarkan dari penelitian kemudian dilakukan kembali uji vadilitas secara berulang sehingga varibel yang masuk ke penelitian valid untuk digunakan. Rumus yang digunakan dalam uji validitas adalah rumus 1 , di bawah ini:

$$
\mathrm{r}_{\text {tot }} \quad=\frac{\mathrm{N}\left(\sum \mathrm{XY}\right)-\left(\sum \mathrm{X} \cdot \sum \mathrm{Y}\right)}{\left[\left(\mathrm{N} \cdot \sum \mathrm{X}^{2}-\left(\_\sum \mathrm{X}^{2}\right) \cdot\left(\mathrm{N} \cdot \sum \mathrm{Y}-\left(\sum \mathrm{Y}\right)^{2}\right)\right]\right.}
$$

$\begin{array}{cll}\underset{\mathrm{R}_{\text {tot }}}{\text { Keterangan : }} & = & \begin{array}{l}\text { koefisien korelasi antar } \\ \text { butir dan total }\end{array} \\ \mathrm{X} & = & \text { Skor butir pertanyaan } \\ \mathrm{Y} & = & \text { Skor total } \\ \mathrm{N} & = & \text { Jumlah responden }\end{array}$

\section{Uji Reliabilitas}

Uji reliabilitas digunakan untuk menguji sejauh mana suatu akat ukur dapat dipercaya atau dapat diandalkan bilamana suatu alat ukur dipakai dua kali atau lebih, maka untuk mengukur gejala yang sama akan menghasilkan pengukuran yang diperoleh relatif konsisten, dengan kata lain reliabilitas menunjukan suatu alat ukur dalam mengukur gejala yang sama dan merupakan kecermatan atau keterpercayaan suatu alat ukur. Rumus yang digunakan dalam uji reliabilitas adalah rumus 2 dibawah ini:

$$
\alpha=\frac{\mathrm{N}}{\mathrm{N}-1}\left[\frac{1-\sum \sigma^{2}\left(\mathrm{Y}_{i}\right)}{\sigma_{\mathrm{x}}^{2}}\right] \text { atau } \alpha=\left[\frac{N R}{1+R(N-1)}\right]
$$




$\begin{array}{lll}\text { Keterangan } & & \\ \mathrm{N} & = & \text { jumlah responden } \\ \boldsymbol{R}^{\prime} & = & \text { rata-rata korelasi intrim } \\ & = & \text { jumlah varian item } \\ & = & \text { varian komposit total }\end{array}$

\section{Analisis faktor}

Analisis faktor merupakan suatu metode yang dapat digunakan untuk mempelajari suatu fenomena dan menganalisis fenomena tersebut sehingga dapat dibuat suatu pola. Analisis faktor dilandasi oleh interpolasi geometrik dan analisis, dengan kata lain analisis faktor mempunyai karakter khusus yaitu kemampuan untuk mengurangi data. Jika terdapat korelasi dari suatu set peubah, maka analisis faktor akan memperlihatkan beberapa pola yang mendasari sehingga data yang ada dapat dirancang atau dikurangi menjadi set faktor atau komponen yang lebih kecil.

\section{Analisis matrik korelasi}

Salah satu tujuan dari analisis faktor adalah memperoleh faktor-faktor yang merupakan korelasi linier dari variabel-variabel awal, oleh karena itu variabel-variabel awal tersebut harus saling berhubungan agar dapat terbentuk model faktor yang sesuai. Hal ini dapat danalisa diawali dengan matrik korelasi. Jika korelasi antara variabel-variabel tersebut kecil, maka tentu saja tidak mungkin bagi variabel-variabel tersebut bergabung membentuk faktor.

\section{Tes Bartlett}

Tes bartlett digunakan untuk menguji hipotesa terhadap matrik korelasi tersebut, apakah matrik korelasi tersebut merupakan matrik identitas atau bukan. Apabila nilai ter bartlett kecil dan signifikan besar, berarti matrik korelasi yang hendak dianalisis merupakan matrik identitas, dengan demikian analisis faktor tidak dapat dilanjutkan pada tahap berikutnya. Tes Bartlett juga digunakan untuk melihat nilai kaiser mayerolkin (KMO) yang digunakan untuk mengetahui apakah metode sampling yang digunakan memenuhi syarat atau tidak. Di samping itu KMO dalam analisi faktor berguna untuk mengetahui apakah data tersebut dapat dianalisis lebih lanjut dengan analisis faktor. Dengan hipotesis nilai $\mathrm{KMO}>0,5$ maka analisi faktor dapat dilanjutkan.

\section{Korelasi Anti-Image}

Matrik korelasi anti-image merupakan indikator lain untuk mengetahui hubungan antara variabel. Korelasi ini merupakan korelasi parsial antara faktor-faktor khusus. Faktor-faktor khusus ini merupakan faktor yang menjelaskan sisa varian data awal yang tidak dapat dijelaskan oleh faktor hasil analisis. Oleh karena itu analisis faktor akan memperoleh hasil yang baik jika korelasi antiimage ini sekecil mungkin.

MSA (Measure of sampling adequency) merupakanhasil bagi antara kuadrat korelasi parsial. Angka MSA berkisar 0 sampai 1, dengan kriteria:

- MSA $=1$, variabel tersebut dapat diprediksi tanpa keselahan oleh variabel yang lain

- MSA >0,5 variabel masih bisa diprediksi dan bisa dianalisis lebih lanjut

- MSA < 0,5 variabel tidak bisa diprediksi dan tidak bisa dianalisis lebih lanjut atau dikeluarkan dari variabel lainnya

Dasar MSA ini akan digunakan untuk menganalisis setiap variabel.

\section{Ekstraksi Faktor}

Tujuan dari ekstraksi faktor adalah menentukan faktor-faktor yang akan dibentuk. Faktor pertama dipilih berdasarkan varians terbesar yang dapat dihitungnya, faktor kedua mencakup varians terbesar kedua, faktor ketiga mencakup varians terbesar ketiga dan seterusnya. Secara berurutan nilai varians akan menurun sampai varians terkecil yang dimiliki oleh faktor terakhir. Jumlah faktor sebanyak-banyaknya sama dengan jumlah variabel, tetapi dengan membentuk faktor sebanyak variabel, berarti analisis tidak dapat dilakukan. Proporsi setiap variabel yang dihitung oleh semua faktor, sebelum analisis faktor adalah satu.

\section{Rotasi Orthogonal Varimax}

Rotasi orthogonal varimax dilakukan untuk mendapatkan loading faktor yang tinggi pada salah satu variabel dan loading faktor yang rendah pada variabel-variabel yang lain.

Pengelompokan faktor didapatkan dengan cara melihat angka koefisien yang terdapat pada baris variabel dan kolom faktor, angka koefisien yang tertinggi (dalam nilai absolut) dari setiap variabel dalam kolom faktor menjadi tanda bahwa 
variabel tersebut mengelompok dalam faktor yang dimaksud.

\section{Korelasi Tabulasi Silang}

Metode tabulai silang merupakan metode penyusunan data yang paling sederhana untuk melihat hubungan antara dua variabel dalam satu tabel.

\section{METODE PENELITIAN}

\section{Prosedur dan pelaksanaan penelitian}

Langkah-langkah yang ditempuh dalam melaksanakan penelitian, meliputi

Hal-hal sebagai berikut: (1) Merumuskan masalah dan tujuan penelitian; (2) Menunjuk tinjauan pustaka; (3) Menentukan alat dan teknik pengumpulan data; (4) Menentukan alat dan teknik pengolahan data; (5) Mnentukan populasi dan sampel; (6) Mengidentifikasi karakteristik responden; (7) Mengidentifikasi variabel penelitian; (8) Menyusun kuesioner; (9) Menyebarkan kuesioner; (10) Menganalisa data; (11) Membuat kesimpulan dan saran

Keterkaitan masing-masing tahap peneliatian sangat erat hubungannya karena hasil tahap sebelumnya akan menentukan proses dan hasil dari tahap berikutnya.

\section{Merumuskan maslah dan tujuan penelitian}

Langkah awal dari penelitian ini adalah merumuskan masalah apa yang hendak dibahas dan dijadikan obyek penelitian, serta menetapkan maksud dan tujuan yang ingin dicapai. Hal ini diuraikan dalam bab I.

\section{Merujuk tinjauan pustaka}

Tinjauan pustaka dilakukan untuk mendapatkan teori-teori yang berhubungan dengan permasalahan dan metode yang dapat digunakan untuk menyelasaikan permasalahan.

\section{Menentukan alat teknik pengumpulan data}

Alat dan teknik pengumpulan data yang dipandang paling efektif dalam penelitian ini adalah kuesioner. Kuesioner ini disebarkan pada responden yang sesuai dengan tujuan penelitian.

\section{Menentukan alat dan teknik pengolahan data}

Pengolahan data dilakukan dengan menggunakan paket program Statistical package social sciences (SPSS) for windows. SPSS merupakan program pengolahan data statistik yang saat ini paling populer. Selain itu, dibanding dengan microsoft Excell, SPSS mampu melakukan pengolahan data-data statistik yang lebih canggih dan luas. Karena under windows, SPSS lebih mudah dipahami dan dipelajari oleh pengolah data pemula.

\section{Menentukan populasi dan sampel}

Pada penelitian ini populasi yang diteliti adalah rumah yang berada di perumahan PERSADA MAS yang berlokasi di jalan jendral ahmad yani km 8,90 Banjarmasin.

Dengan asumsi bahwa perumahan ini merupakan salah satu perumahan yang sedang berkembang di wilayah Banjarmasin dan para penghuni dianggap sudah mempunyai pengalaman tinggal didaerah perumahan serta memiliki sarana dan prasarana yang mendekati variabel yang akan disusun oleh peneliti (misalnya kenyamanan lingkungan dsbnya). Tipe rumah yang akan diambil dalam sampel penelitian yaitu tipe 76 , tipe 100 dantipe 150 . Pemilihan rumah yang diambil sebagai sampel dilakukan ddengan cara purposive sampling, yaitu metode sampel yang diambil berdasarkan kondisi lapangan dengan pertimbangan memudahkan dalam proses pendataan konsumen dan penyesuaian terhadap kondisi pada saat di lokasi pengambilan sampel. Populasi rumah dalam hal ini dianggap satu rumah satu kepala keluarga.

\section{Mengidentifikasi karakteristik responden}

Tahapan identifikasi karakteristik responden penelitian ini mencakup variabel yang dipilih, yaitu: (1) Nama; (2) Jenis kelamin; (3) Status perkawinan; (4) Lokasi perumahan; (5) Tipe rumah; (6) Pekerjaan; (7) Jumlah Penghasilan; (8) Jarak rumah ke tempat kerja; (9) Sarana ke tempat kerja; (10) Jumlah anak; (11) Alasan membeli rumah; (12) Kegunaan setelah memiliki rumah; (13) Tindakan setelah memiliki rumah; (14) Rumah direnovasi/tidak

\section{Mengidentifikasi variabel penelitian}

Langkah selanjutnya adalah observasi langsung variabel penelitian. Informasi awal yang 
dibutuhkan berupa variabel apa saja yang dianggap paling dominan tentan kepuasan konsumen dalam pembelian rumah. Informasi mengenai variabel ini dilakukan dengan cara melihat situasi dan kondisi di lapangan. Variabel yang didapatkan dikelompokan berdasarkan masing-masing kategori yang diberi bobot nilai. Bobot nilai diasumsikan berdasarkan tingkat variabel yang dianggap paling penting/utama dalam pemenuhan kebutuhan konsumen perumahan (lihat bab II aspek pemenuhan konsumen perumahan). Semakin penting/utama kepentingan suatu variabel dalam pemenuhan kebutuhan perumahan maka semakin besar bobot yang diberikan. Kelompok variabel itu adalah:

Kelompok variabel dengan bobot 1 :Warung/toko, tempat bermain/taman, cara pembayaran

Kelompok variabel dengan bobot 2: Jarak ke kendaraan umum, jarak ke pasar lokal, jarak ke balai pengobatan, arak ke sekolah

Kelompok variabel dengan bobot 3: Sarana pendidikan, sarana kesehatan, sarana olahraga, sarana ibadah, harga rumah, lebar jalan perumahan, saluran air kotor, tempat pembuangan sampah

Kelompok variabel dengan bobot 4: Luas rumah, kemungkinan pengembangan, keamanan lingkunga, kenyamanan lingkungan, keamanan tehadap banjir

Kelompok variabel dengan bobot nilai 5:Lokasi perumahan, bentuk/tipe rumah, mutu/kondisi rumah, fasilitas listrik, fasilitas air bersih

Dalam penelitianini, pengelompokan pembobotan digolongkan menjadi sangat penting bobot 5, penting bobot 4, sedang bobot 3 ,kurang pentingbobot 2 dan tidak penting bobot 1 .

\section{Menyusun kuesioner}

Kuesioner penelitian terbagi atas dua bagian, yaitu: (1) bagian pertama dari kuesioner bertujuan untuk memperoleh data demografi, sosio-ekonomi dan pelaku konsumen lainnya. Hal ini untuk membedakan karakteristik responden yang satu dengan yang lainnya; (2) bagian kedua dari kuesioner bertujuan untuk memperoleh data atau penilaian mengenai atribut-atribut yang terdapat pada perumahan dengan cara memberikan pendapat, sangat puas,puas,sedang,tidak puas dan sangat tidak puas.

Jadi kuesioner I berisi karakteristik konsumen dan kunsioner II adalah penilaian konsumen terhadap 25variabel yang telah di tentukan dan prioritas serta harapan konsumen dalam membeli rumah di perumahan persada mas.

\section{Menyebarkan kuesioner}

Kuesioner disebarkan dengan cara menyerahkan langsung kepada responden yang telah ditetapkan sebelumnya berdasarkan kondisi dilapangan atau melalui perantara penyebaran kuesioner yang dapat dipercaya. Sebelum kuesioner dibagikan perlu diberikan penjelasan kepada responden maupun perantara penyebaran kuesioner tentang isi dan cara pengisiannya. Hal ini dilakukan agar dalam pengisian kuesioner tersebut tudak terjadi kesalahan. Kuesioner dibagi sebanyak 37 buah kuesioner, hal ini untuk mengantisipasi terjadinya missing data, missing data adalah adanya sel-sel kosong pada satu atau beberapa variabel pertanyaan.

\section{Menganalisa data}

Data yang diperoleh melalui kuesioner I diolah dengan membuat distribusi frekuensi. Dari distribusi frekuensi yang dibuat akan diketahui deskripsi konsumen. Untuk menganalisa data yang diperoleh dari kuesioner II, penulis melakukan uji validitas dan uji reliabilitas untuk masing-masing variabel pada kuesioner II yang dilakukan pada 30 responden. Apabila variabel valid akan diuji ulang sedangkan yang tidak valid dibuang. Setelah hasil uji kedua variabel keseluruhan variabel valid maka dilihat apakah reliabel atau tidak dengan melihat nilai cronbach alpha. Apabila reliabel pengujian dilanjutkan apabila tidak kembali ke awal lagi yaitu penyebaran kuesioner.

\section{HASIL DAN PEMBAHASAN}

Ada 3 kuesioner:

Tabel 1. Kuesioner I (Karakteristik Responden)

\begin{tabular}{|l|l|l|l|l|}
\hline No & \multicolumn{1}{|c|}{ Kuesioner } & \multicolumn{1}{|c|}{ Variabel } & Jumlah Responden & \multicolumn{1}{c|}{ Uraian } \\
\hline 1 & Kuesioner I: & $\begin{array}{l}\text { Jenis Kelamin } \\
\text { responden }\end{array}$ & 30 orang & $\begin{array}{l}\text { Laki-laki (16), dan perempuan } \\
\text { (14) }\end{array}$ \\
\cline { 3 - 5 } & \multirow{2}{*}{ Karakteristik Responden } & $\begin{array}{l}\text { Status } \\
\text { perkawinan }\end{array}$ & 30 orang & Kawin (28), cerai mati (2) \\
\cline { 3 - 5 } & & &
\end{tabular}




\begin{tabular}{|c|c|c|c|c|}
\hline No & Kuesioner & Variabel & Jumlah Responden & Uraian \\
\hline & & responden & & \\
\hline & & $\begin{array}{l}\text { Luas bangunan } \\
\text { tipe ruma } \\
\text { responden }\end{array}$ & 30 orang & $\begin{array}{l}\text { Tipe } 76(10) \text {, tipe } 100(10) \text {, } \\
\text { tipe } 150(10)\end{array}$ \\
\hline & & $\begin{array}{l}\text { Pekerjaan } \\
\text { responden }\end{array}$ & 30 orang & $\begin{array}{l}\text { Wiraswasta, (17) karyawan } \\
\text { swasta (11) pegawai negeri (2) }\end{array}$ \\
\hline & & $\begin{array}{l}\text { Jumlah } \\
\text { penghasilan }\end{array}$ & 30 orang & $\begin{array}{l}\text { Rp. } 5 \text { jt }-10 \text { jt (8), Rp } 10 \text { jt }-20 \\
\text { jt (7), >20 jt (13) }\end{array}$ \\
\hline & & $\begin{array}{l}\text { Jarak dari rumah } \\
\text { ke tempat kerja }\end{array}$ & 30 orang & $\begin{array}{l}\text { Kurang dari } 1 \mathrm{~km}(4), 5 \mathrm{~km}-10 \\
\mathrm{~km}(21),>10 \mathrm{~km}(5)\end{array}$ \\
\hline & & $\begin{array}{l}\text { Sarana responden } \\
\text { ke tempat kerja }\end{array}$ & 30 orang & Sepeda motor (3), mobil (27) \\
\hline & & $\begin{array}{ll}\text { Jumlah } & \text { anak } \\
\text { responden } & \\
\end{array}$ & 30 orang & $\begin{array}{l}! \text { orang (7) } 2 \text { orang (15) } 3 \\
\text { orang (8) }\end{array}$ \\
\hline & & $\begin{array}{l}\text { Alasan responden } \\
\text { membeli rumah }\end{array}$ & 30 orang & $\begin{array}{l}\text { Belummemilikirumah } \\
\text { investas (12) lainnya (9) }\end{array}$ \\
\hline & & $\begin{array}{l}\text { Kegunaan } \\
\text { responden } \\
\text { memiliki rumah }\end{array}$ & 30 orang & $\begin{array}{l}\text { Di tempati sendiri (17), } \\
\text { disewakan (13) }\end{array}$ \\
\hline & & $\begin{array}{l}\text { Tindakan } \\
\text { responden setelah } \\
\text { memiliki rumah }\end{array}$ & 30 orang & $\begin{array}{l}\text { Renovasi (20), tidakdirenovasi } \\
\text { (10) }\end{array}$ \\
\hline & & $\begin{array}{l}\text { Alasan responden } \\
\text { merenovasi }\end{array}$ & 30 orang & $\begin{array}{l}\text { Bentuk tidak sesuai (7), luas } \\
\text { tidak sesuai (13) }\end{array}$ \\
\hline
\end{tabular}

Tabel 2. Kuesioner II (Prioritas Responden)

\begin{tabular}{|c|c|c|c|c|}
\hline \multirow[t]{9}{*}{2.} & Kuesioner II: & $\begin{array}{l}\text { Prioritas terhadap } \\
\text { fasilitas listrik }\end{array}$ & 30 orang & $1(27), 2(3)$ \\
\hline & \multirow[t]{8}{*}{ Prioritas Responden } & $\begin{array}{l}\text { Prioritas terhadap } \\
\text { fasilitas air bersih }\end{array}$ & 30 orang & $1(3), 2(27)$ \\
\hline & & $\begin{array}{l}\text { Prioritas terhadap } \\
\text { telpon }\end{array}$ & 30 orang & $3(21), 4(2), 5(2), 6(5)$ \\
\hline & & $\begin{array}{l}\text { Prioritas terhadap } \\
\text { pendidikan }\end{array}$ & 30 orang & $3(12), 4(9), 5(9)$ \\
\hline & & $\begin{array}{l}\text { Prioritas terhadap } \\
\text { kesehatan }\end{array}$ & 30 orang & $3(13), 4(5), 5(12)$ \\
\hline & & $\begin{array}{l}\text { Prioritas terhadap } \\
\text { olahraga }\end{array}$ & 30 orang & $2(6), 3(8), \$(14)$ \\
\hline & & $\begin{array}{l}\text { Prioritas terhadap } \\
\text { ibadah }\end{array}$ & 30 orang & $1(13), 2(5), 3(12)$ \\
\hline & & $\begin{array}{l}\text { Prioritas terhadap } \\
\text { tempat } \\
\text { bermain/taman }\end{array}$ & 30 orang & $2(18), 3(7), 4(5)$ \\
\hline & & $\begin{array}{l}\text { Prioritas terhadap } \\
\text { pasar }\end{array}$ & 30 orang & $3(11), 4(8), 5(11)$ \\
\hline
\end{tabular}

Tabel 3. Kuesioner III (Harapan Responden)

\begin{tabular}{|l|l|l|l|l|}
\hline 3. & Kuesioner III: & $\begin{array}{l}\text { Harapan terhadap lebar } \\
\text { jalan utama }\end{array}$ & 30 orang & $5 \mathrm{~m}-10 \mathrm{~m}(22),>10 \mathrm{M}(8)$ \\
\cline { 3 - 4 } & Harapan Responden & $\begin{array}{l}\text { Harapan terhadap lebar } \\
\text { jalan perumahan }\end{array}$ & 30 orang & $5 \mathrm{~m}-1 \mathrm{~m}(30)$ \\
\cline { 3 - 4 } & & &
\end{tabular}




\begin{tabular}{|l|l|l|l|}
\hline $\begin{array}{l}\text { Harapan terhadap jalan } \\
\text { yang diinginkan }\end{array}$ & 30 orang & Paving (6), aspal (23), beton (1) \\
\hline $\begin{array}{l}\text { Harapan terhadap daya } \\
\text { listrik } 30 \text { orang }\end{array}$ & $\begin{array}{l}\text { 1300 watt (9), 2200 watt (7) .2200 watt } \\
(14)\end{array}$ \\
\hline $\begin{array}{l}\text { Harapan terhadap } \\
\text { fasilitas olahraga }\end{array}$ & 30 orang & $\begin{array}{l}\text { Kolam renangg (14), basket (10), } \\
\text { volley (6) }\end{array}$ \\
\hline $\begin{array}{l}\text { Harapan terhadap } \\
\text { fasilitas pendidikan }\end{array}$ & 30 orang & TK (13), SD (15), SMP (2 \\
$\begin{array}{l}\text { Harapan terhadap } \\
\text { fasilitas kesehatan }\end{array}$ & 30 orang & Klinik (5), dokter (12), rumah sakit (13) \\
\hline
\end{tabular}

Dari hasil analisis didapatkan 3 faktor dominan tentang kepuasan konsumen dalam membeli rumah yaitu faktor dominan pertama yang terdiri dari variabel fasilitas air bersih, fasilitas listrik, lebar jalan utama dan warung/toko dengan skor rata-rata $50,17 \%$, faktor dominan kedua terdiri dari variabel sarana pendidikan, sarana kesehatan, sarana olahraga, sarana ibadah, dan tempat berbmain dengan skor $23,53 \%$ dan faktor dominan ketiga yag meliputi variabel mutu/kondisi rumah dan keamanan terhadap banjir dengan rata-rata skor $22,10 \%$. Hasil analisis ini sesuai dengan prioritas dan harapan konsumen perumahan.

\section{PENUTUP}

\section{Kesimpulan}

Dari hasil analisis data dan pembahasan dapat disimpulkan sebagai berikut:

- Faktor dominan pertama yang didapatkan sebagai faktor dominan tentang kepuasan konsumen dalam pembelian rumah adalah faktor 2 dengan skor 50,17\% yang meliputi variabel fasilitas air bersih, fasilitas listrik, lebar jalan utama dan warung/toko.

- Faktor dominan kedua yang didapatkan sebagai faktor dominan tentang kepuasan konsumen dalam pembelian rumah adalah faktor 1 dengan skor $23,53 \%$ yang meliputi variabel sarana pendidikan, sarana kesehatan, sarana olahraga, sarana ibadah dan tempat bermain

- Faktor dominan ketiga yang didapatkan sebagai faktor dominan tentang kepuasan konsumen dalam pembelian rumah adalah faktor 3 dengan rata-rata skor 22,10\% yang meliputi variabel mutu/kondisi rumah dan keamanan terhadap banjir

\section{Saran}

- Untuk lebih memuaskan konsumen perumahan pihak developer agar segera merealisasikan membangun fasilitas umum yang telah direncanakan pada tahap perencanaan perumahan. Dengan demikian, diharapkan sarana/fasilitas yang dibangun akan memiliki nilai ganda yaitu untuk memenuhi kewajiban dan janji pengembang pada awal penawaran perumahan dan juga dapat memenuhi kebutuhan konsumen yang mendiami rumahdi perumahan tersebut. Dengan adanya sarana/fasilitas ini tentu akan menjadi sarana promosi dalam menjual produk perumahan dan menarik konsumen lain untuk membeli rumah pada perumahan.

- Hasil data prioritas konsumen dan harapan konsumen sebagai masukan bagi pengembang dalam peningkatan kualitas perumahan dengan memenuhi prioritas konsumen dan harapan konsumen tersebut. Sehingga kepuasan konsumen terhadap produk perumahan semakin meningkat.

- Sedangkan untuk penelitian selanjutnya sebaiknya butir pertanyaan pada kuesioner lebih bervariatif, jumlah responden lebih banyak agar gambaran tentang kepuasan konsumen akan semakin jelas, pengisi kuesioner tidak hanya kepala keluarga tetapi juga anggota keluarga yang menempati rumah di perumahan tersebut, populasi dan sampel penelitian beragam tidak hanya I perumahan saja.

\section{DAFTAR PUSTAKA}

Barkley, Bruce T, \& James H. Saylor, (1994), Customer Driven Project Management: A New Paradign in Total Quality 
Implementation, Singapore: Mc. GrawHill. Inc

Cahyana, Jaka, \& Sudaryatmo, (2004), Panduan Membeli Rumah Hunian, Elexmedia Komputindo, Jakarta

Direktorat Tata Kota dan Tata Daerah bekerja sama dengan Direktorat Pendidikan Masalah Bangunan, (1983). Pedoman Perencanaan Lingkungan Pemukiman Kota

Kotler, Philip, Amstrong, Gary, (1997). Dasardasar Pemasaran, Prehallindo, Jakarta

Mangkunegara, AnwarPrabu, (2002), Perilaku Konsumen, Reflika Aditama, Bandung

Saifuddin, Azwar, (1997), Validitas dan Reliabilitas, Pustaka Pelajar Offset, Yogyakarta
Santoso, Budi, (2000), Real Estate Sebuah Konsep Ilmu dan Problema Pengembang Indonesia, Jakarta

Santoso, Singgih, (2002), SPSS Statistik Multivariat, Elex Media Komputindo Kelompok Gramedia, Jakarta

Sugandi, Machmud, (2002), Jurnal Bangunan: Kepuasan Pelanggan Sebagai Fokus Implementasi Manajemen Kualitas di dalam Suatu Proyek PembangunanREal Estate, Malang: Jurusan Teknik Sipil Fakultas Teknik Universitas Negeri Malang

Suhaemi, Uzair, (2003), Materi Kuliah Validitas dan Reliabilitas, Sekolah Tinggi Ilmu Statistik, Jakarta

Supranto, J. (2001), Pengukuran Tingkat Kepuasan Pelanggan Untuk Menaikan Pangsa Pasar, Rineka Cipta, Jakarta 